\title{
A Study of Apogamy in Nephrodium hirtipes, Hk.
}

\author{
BY \\ W. N. STEIL, \\ University of Wisconsin, Madison, Wisconsin, U.S.A.
}

With Plates V-VII.

\section{INTRODUCTION.}

$T$ HE first reported observation of a sporophyte tissue element in the cells of a fern gametophyte was made by Leszcyc-Suminski (1848), who found tracheides near the apical notch of the prothallium of Pteris sulcata, L.

Wigand (1849) described a cylindrical or conical process produced as an outgrowth from the apical notch of the fern prothallium, instances of this sort being found in several cultures. According to his description, the embryo begins its development on the ventral side of the prothallium and at the posterior portion of the process. Since there can be no certainty regarding the purity of his cultures, the peculiar developments described cannot be referred to any particular species. There can be no doubt, however, from his descriptions (1.c., pp. I06, 107) and figures (Figs. 25-9) that he studied embryos of apogamous origin.

Mercklin (1850) found cells in the prothallium of Pteris sulcata like those observed by Leszzzyc-Suminski. Mercklin also figured (1.c., PI. VII, Fig. 6) a.prothallium and a young embryo of Nothochlaena Eckloniana. Mercklin's figure, although somewhat diagrammatic, suggests that the embryo had been apogamously produced. Over a half-century later Woronin (1907) found apogamy in the same species.

Farlow (1874) discovered apogamy in Pteris cretica albo-lineata, and was first to recognize clearly the nature of an apogamous embryo as distinguished from one resulting from fertilization. He described the origin of the embryo as an asexual outgrowth from the prothallium. When the embryo is about to begin its development, the portion of the prothallium posterior to the apical notch becomes pale, and tracheides appear in the nearly colourless region. A process, similar to that described by Wigand, develops from the apical notch. The embryo is now produced on the ventral surface of the prothallium posterior to the apical region. The leaf

[Annals of Botany, Vol. XXXIIl. No. CXXIX. January, igrg.] 
appears first, then the root, and later the stem. A foot is never formed. Between the cells of the gametophyte and those of the apogamous embryo there is no sharp line of distinction. The vascular system of the embryo is intimately connected with vessels in the prothallium. These characters described by Farlow for Pteris cretica have been found by other investigators in a number of apogamous ferns. In the same year Abbot (1874) reported apogamy in an unidentified fern.

De Bary (1878) extended Farlow's observations on Pteris cretica and also tested a large number of other species to determine the extent of apogamy in ferns. He found it to occur in Aspidium falcatum and A. Filix-mas var. cristata. The development of the embryo in both these species is similar to that described by Farlow for Pteris cretica.

Sadebeck (1879) reported apogamy in Todea africana. Leitgeb (1885) reported it as occurring occasionally in Osmunda regalis and Ceratopteris thalictroides. His observations on the two latter species have, however, never been confirmed. Stange (1887) discovered apogamy in Doodya caudata, Todea pellucida, and $T$. rivularis. Berggren (1888) described it in Nothochlaena distans.

The development of the apogamously produced embryos of Doodya candata was investigated by Heim (1896). Since archegonia and antheridia appear to develop to maturity in this species, Heim believed that fertilization may also occur. Archegonial and antheridial 'projections' are developed on the prothallia, and these projections produce the apogamous embryos. As many as thirty projections may be formed on a single prothallium, but only a few embryos. produced will survive.

Bower (1888) discovered apogamy in Trichomanes alatum. Although spores are ordinarily formed in this species, apospory commonly occurs. The prothallia thus developed give rise to the apogamous embryos.

Lang (1898) induced apogamy in the following species of ferns, the prothallia of which were grown under special cultural conditions for a period of two and a half years: Scolopendrium vnlgare, Sw., vars. ramulossisimum, Woll., and marginale, Nephrodium dilatatum, Desv., var. cristatum gracile, Neplirodium Orcopteris, Desv., var. coronans, Barnes, Aspidium. aculeatum, Sw., var. multifidum, Woll., A. angulare, Willd., vars. foliosum multifidum and acutifolium multifidum, A. frondosum, Lowe, A. thyrium, Mett., var. nipponicum and var. cristatum, $A$. Filix-foemina, Bernh., vars. percristatum, Cousens, cruciato-cristatum and coronatum, Lowe, and Polypodium inlgare, L., var. grandiceps, Fox. By watering the cultures from below and keeping them in strong light, Lang believed that apogamy was induced. He was inclined to think that the high temperature under which the prothallia were grown may have been a factor in inducing the appearance of the sporophytic structures, although he believed that the prevention of fertilization was the most important condition. 
In all the ferns which Lang placed under these cultural conditions, excepting Aspidium angulare, Willd., var. acutifolium multifidum, apogamy was induced. He believed that if the prothallia of this variety had been maintained under the cultural conditions for a longer period of timc, apogamy might have resulted. In all species excepting Pclypodium vulgare, archegonial projections were produced. From processes that appeared on the prothallia of Scolopendium vulgare, Sw., var.ramulossisimum, Woll., and Nephrodium dilatatum, Desv., sporangia were formed. The apogamous formation of sporangia in these cases is analogous to the development of antheridia directly on the fern leaf. A case of apospory of this nature was later described by Woronin (1907) in Trichomanes Kraussii. The cultural conditions which Lang maintained were evidently not uniform, since in every culture some embryos were produced as a result of fertilization. No control cultures were used by Lang, and, although he exercised great care in his cultural work, no positive conclusion can be drawn from his results regarding the actual conditions which induced apogamy.

In a preliminary note, Farmer; Moore, and Digby (1903) reported nuclear migrations and fusions in the vegetative cells of the prothallium of Lastraea psendo-mas. A diploid nucleus was thus established in some of the cells by a fusion in pairs of the nuclei of adjacent cells. The apogamous embryo, according to their description, begins its development from cells whose nuclei have the double number of chromosomes, the latter being acquired as a result of the 'irregular' fertilization or 'substitution' fusions. Such fusions, as described by these investigators, are the first to be reported in ferns.

Miss Digby (1905) found no reduction in chromosome number in the life-history of the apogamous Nephrodium pseudo-mas, Rich., var. cristata, fifty chromosomes being counted in the cells of both generations. Nuclear migrations were found in 73 per cent. of the prothallia of the apogamous Neplirodium psendo-mas, Rich., var. polydactyla, Wills.

Farmer and Digby (1907) later published a more extensive account of their cytological investigations of apospory and apogamy in ferns. Of the seven forms studied by them, the following were parthenogenetic and aposporous: Athyrium. Filix-focmina var. clarissima, Bolton, A. Filixfoemina var. unco-glomeratum, Stansfield, and Scolopendrium vulgare, var. crispum Drummondae. The prothallia of Athyrium Filix-foemina var. clarissima, Jones, and Lastraea pseudo-mas var. cristata apospora were produced aposporously. In the former archegonia were produced, but the cmbryo, as also in the latter species, always originated as a vegetative outgrowth of the gametophytc. In Lastraca (Nephrodium) pseudo-mas var. polydactyla, Wills, and L. pseudo-mas var. polydactyla, Dadds, the prothallia were produced from spores. Archegonia were never formed, and the embryo 
in these, as in the two previously mentioned forms, originated as a vegetative outgrowth.

So far as the nuclear history of apogamous ferns is concerned, that of the polydactyla varieties is of great interest. Nuclear migrations and fusions were observed by Farmer and Digby to occur between adjoining cells posterior to the apical region of the prothallium. From such a fusion or 'irregular fertilization' the apogamous embryo originated. In all the cases of induced apogamy, Farmer and Digby assume that similar migrations and fusions occur previous to the formation of the embryo. This conclusion is based not alone on their investigations, but on the observations of Lang (1898), who found binucleate cells in the prothallia of some of the ferns in which he believed that he had induced apogamy (his Fig. 2, Pl. VIII). Heim (1896) also figured such cells in the prothallia of Doodya caudata (p. 338, Fig. 7). Stephens and Sykes (1910) found binucleate cells in the prothallia of Pteris droogmantiana, which, however, resulted from a nuclear division not followed by cell division. Although Stephens and Sykes assumed the occurrence of apogamy in Pteris droogmantiana in their preliminary report, so far as I am aware no further contribution has yet appeared dealing with apogamy in this fern.

Farmer and Digby (1907) made a detailed study of the chromosome number in the apogamous and parthenogenetic species. In Athyrium Filix-foemina var. clarissima, Bolton, eighty-four chromosomes were counted in both generations. Ninety chromosomes were found to be present throughout the life-history of $A$. Filix-foemina var. clarissima, Jones, and one hundred were counted in both generations of $A$. Filix-foemina var. unco-glomeratum, Stansfield. In each of these cases the number of chromosomes present is, they conclude, presumably the sporophytic number. The nuclei of the prothallial cells of Scolopendrium vulgare var. crispum Drummondae contain eighty chromosomes, but one hundred were found in the cells of the embryo. Between sixty and seventy-eight chromosomesprobably the gametophytic number-were observed in the nuclei of the aposporous Lastraea pseudo-mas var. cristata apospora. From sixty-four to sixty-six chromosomes were found in nuclei of the gametophyte of Lastrea psendo-mas vars. polydactyla, Wills and Dadds, and from one hundred and twenty-eight to one hundred and thirty-two in the sporophytic nuclei. The double number was, according to their description, established by the fusions of the nuclei in the prothallial cells.

Goebel (1905) found apogamy to occur in Trichomanes Kraussii and Peilaea nivea.

Woronin $(1907,1908)$ discovered apogamy in Pellaea tenera, P. favens, Nothochlaena Eckloniana, and $N$. sinuata. Woronin investigated these cases and also the apogamy of the species reported by Goebel. Archegonia were never produced on the prothallia of any of these species, although normal 
antheridia were produced in all cases except Trichomancs Kraussii, in which they aborted before reaching maturity. Woronin holds that the Pellaea and Nothochlaena species have become apogamous on account of the xerophytic conditions under which they live. It is assumed that such an environment, being unfavourable for fertilization, may have led to the development of apogamy.

Yamanouchi (1908 c) reported the occurrence of apogamy in Neplirodium molle, Desv., the prothallia of which had been watered from below and kept in direct sunlight. He had shown that fertilization and sporogenesis normally occur in this fern, and hence was certain that the apogamy which he observed had been induced by the cultural conditions. The apogamous sporophyte is described as having the gametophytic number of chromosomes, namely from sixty-four to sixty-six. It is to be regretted that none of the sporophytes thus produced were grown to maturity. A study of sporogenesis, if spores were formed at all, would be of especial interest. According to Yamanouchi, the apogamous sporophyte began its development in a comparatively short period after the prothallium assumed the heart-shaped form and when the archegonia are ordinarily produced. Hence a long period of time does not appear to be necessary to induce apogamy, as seemed to be the case in Lang's experiments.

Miss Black (1909) has duplicated so far as possible with the same species the cultural conditions used by Yamanouchi for inducing apogamy in Nephrodium molle. She also grew the prothallia of Dryopteris stipularis under the same conditions. Although the prothallia of both species were watered from below and kept in strong light, they developed to a large size and produced sex-organs. At no time were sporophytes produced in any of the cultures so treated.

Mottier (1915) also attempted to show the effect of dry cultural conditions and strong light on the development of apogamous embryos. He grew the prothallia of both the species which Miss Black had used, as well as those of Onoclea Struthiopteris. Mottier also was unable to induce the appearance of a single apogamous sporophyte. On the basis of this work and of a study of the normally produced embryo of Nephroditum molle, Mottier questions whether Yamanouchi was actually dealing with an apogamously produced embryo.

Heilbronn (1910) found among the prothallia of a culture of Asplenium Ruta-muraria prothallia which he identified as those of Cystopteris fragilis. The latter were isolated, and their further development was studied. It was observed that in the stronger illumination of summer, embryos were produced apogamously as outgrowths both of the vegetative cells of the prothallium and of the sex-organs. Later in the season, when the illumination was weaker, the projections like those which during the summer formed 
embryos now produced antheridia and archegonia, and sporophytes developed only as a result of fertilization. The following summer the new projections again "formed apogamous embryos. Heilbronn attributed the occurrence of apogamy to intense illumination, although he failed to obtain similar results in some other species placed under the same conditions. Some differences were observed between the two types of embryos of Cystopteris fragilis, but it was not determined whether the spores produced by the apogamously formed sporophytes would produce prothallia of the normal Cystopteris form, or those of the apogamous form which Heilbronn distinguished as Cystopteris forma polyapogama. Heilbronn also found apogamy in Aspidium aculeatum var. cruciato-polydactylum, Jones, and $A$. angulare forma grandidens, Moore.

:In several instances Miss Pace (1913) found on prothallia, probably of a species of Osmunda, sporangia similar to those described by Lang (1898). The prothallia had been grown for a long period, but were not subjected either to dryness or to strong illumination. She considered the prevention of fertilization by watering from below to be the cause of the formation of the apogamous embryos.

Nagai (1914) obtained apogamous embryos of Asplenium nidus avis when the cultures were lacking in moisture, but he believed that high temperature and strong light may also be factors in inducing apogamy.

Miss Allen (1911) studied the cytology of Aspidizm falcatum, in which de Bary had discovered apogamy in 1878. According to her description there is a fusion in pairs of the sixteen cells which ordinarily in the Polypodiaceae function as the spore mother-cells. The eight cells produced by this fusion function as the spore mother-cells. By the nuclear fusion the double chromosome number is established, but the reduction division follows the fusion, so that the thirty-two spores which are finally formed. contain the haploid number of chromosomes.

In a preliminary note (Steil, 1915 b) I have reported a course in Nephrodium hirtipes similar to that described by Miss Allen. Further stidies, as will be indicated in what follows, have led me to modify in certain respects the conclusions which I first formed regarding the cytological basis of apogamy in this species.

For the past six years I have grown the prothallia of a number of specics of ferns for the purpose of determining the occurrence of apogamy and of investigating, so far as possible, the cytology of the apogamous forms. I have reported apogamy in Pellaea atropurpurea, L. (Steil, 1910), and later (Steil, 1915 a) in P. adiantoidis, J. Sm, Aspidium chrysoloba, A. tsussimense, and Nephrodizm hirtipes, $\mathrm{Hk}$. I have also found it to occur in Pellaca atropurpurea var. cristata, Trei., P. hastata, L., Aspidium falcatum Rockfordianum, A. falcatum Fortunei, A. falcatum caryotidium, Pteris sulcata, L., Pteris argyrea, Moore, Pteris Parkeri, and in a number of 
varieties of Ptcris cretica (Steil, 1918). Antheridia are produccd on the prothallia of all the spccies in which I have observed the development of apogamous embryos. Archegonia arc, however, developed in only a few of these species. Cytological studies of the apogamous ferns have already been begun, and in several species the history of the sporogenous cells appears to be similar to that herein described for Nephrodium hirtipes.

In all the apogamous ferns wbich have so far been investigated, antheridia appear to be developed except in Trichomanes alatum and T. Kraussii. In these two species antheridia never develop to maturity. In numerous cultures of the prothallia of Pellaea atropurpurea, L., antheridia were found by the writer, but under certain cultural conditions they frequently appear in large numbers. In a number of species archegonia are never produced, in a few they abort, and in still others they are apparently developed to maturity. Whether fertilization occurs in the latter cases, as reported by Heim (1896) and Heilbronn (1910) for some of the apogamons species, is a question that must be left for further investigation.

\section{Materials AND Methods.}

The reader is referred to my preliminary note on Nephrodiumn hirtipes $(1915 \mathrm{~b})$ for a brief description of the cultural conditions under which the prothallia were grown. In the many cultures which have been made since the discovery of apogamy in this species, no important differences have been observed in the development of the prothallia or in that of the apogamously produced embryos.

The spores of Nephrodium hirtipes from which the prothallia were grown were collected from plants grown in the university greenhouse. Five of these plants were obtained from the first culture of the prothallia made December 14, I9I3. The others were obtained from different sources.

The rate of growth and the size of the prothallia were affected by the strength of the nutrient solution, the temperature, the moisture, and the illumination. Too intense illumination was avoided by shading. The moisture supply was sufficient to allow fertilization to occur in all of the numerous non-apogamous species which have been grown under the samc conditions as Nephrodium hirtipes. The temperature of the Wardian case in which the prothallia were grown varied from $70^{\circ} \mathrm{F}$. in winter to about $110^{\circ} \mathrm{F}$. in the hottest days of summer. While a $0^{\circ} \mathrm{I}$ per cent. Knop's solution was generally used for the prothallia grown on sphagnum, various strengths of this solution were used and the spores were sown also on the surface of the liquid medium. Beyerinck's solution as modified by Moore (1903) also proved very satisfactory. By tilting the bell-jars which were placed over the uncovered Stender dishes with the growing prothallia, an abundant supply of oxygen and carbon dioxide was provided. 
So far as possible an attempt was made to check the influence of the cultural conditions on the development of archegonia and the formation of embryos of apogamous origin. When spores were sown on soil in different parts of the greenhouse the prothallia of Nephrodium hirtipes always produced embryos apogamously. Variations in the illumination, the strength of the nutrient solution, or the temperature, resulted neither in the production of archegonia nor in any essential difference in the manner of formation of the embryos. A number of species of ferns in which fertilization is known to occur were also grown in the Wardian case, but they never produced embryos apogamously under these conditions.

Spores of Asplenium nidus avis and Nephrodium molle obtained through the kindness of Dr. George T. Moore, Director of the Missouri Botanical Garden, were sown, and the resulting prothallia were also subjected to the same cultural conditions under which the prothallia of Nephrodium hirtipes were grown. In both species antheridia and archegonia were produced in large numbers and embryos appeared only as a result of fertilization. Therefore, my cultural conditions were not such as to induce apogamy in Asplenium nidus avis, in which it was observed by Nagai (1914), or in Nephrodium molle, in which induced apogamy was reported by Yamanouchi (1908 c).

In preparing material for cytological study, various fixing agents were used. By far the best preparations were obtained with the Flemming fluids. Flemming's weaker solution gave the best results for the prothallia and the young embryos; the Flemming medium solution proved most satisfactory for work on the sporogenous cells. Sections were cut usually five or six microns in thickness. For some of the studies of the sporogenous cells, sections were made eight or ten microns in thickness. Although a number of stains were used, Flemming's triple stain (safranin, gentian violet, and orange $G$ ) gave the best results.

\section{OBSERVATIONS.}

\section{The Gametophyte of Nephrodium hirtipes.}

The spores of Nephrodium hirtipes usually remain capable of germination for about a month after they mature, although some of them retain their germinating power for a much longer period.

The spores germinate within a few days after they are sown. Nothing unusual was observed in the germination of the spores or in the early stages of development of the prothallia. The prothallia become typically heartshaped (Figs. I-3, P1. V). Glandular hairs are produced on both surfaces, especially on the anterior portion and along the margins of the prothallium. Archegonia are never produced, and antheridia are not formed, as a rule, under ordinary cultural conditions. Spermatogenesis has not been studied 
in detail, but, so far as I have observed, it seems normal in every respect. The antherozoids are actively motile.

Secondary prothallia were readily induced, 'and these resembled in all essential respects the primary prothallia, producing, like them, apogamous sporophytes. I have also found that in some other apogamous species, including Pellaea atropurpurea, Pteris cretica albo-lineata, and Pteris sulcata, secondary prothallia produce apogamously sporophytes.

Numerous attempts were made to induce apospory in Nephrodium lirtipes by methods which have been described by different investigators to bring about aposporous development of the gametophyte in other ferns, such as placing the leaves of young sporophytes in contact with the soil, attaching to the soil leaves and fronds of older plants, placing portions of leaves on moist soil or sphagnum, and growing prothallia-bearing young embryos in weak light. So far, only the last method has been successful to a very limited degree. Occasionally when prothallia with very young embryos were placed in subdued light, the apical region of the prothallium, frequently almost colourless grew forward into a long cylindrical or conical process, and on the new portion it was observed that after the primary leaf had begun its development as a direct outgrowth of the prothallium, its proximal portion, instead of forming a lamina typical in form and structure, became branched and gradually prothalloid. A root, so far as I could determine, was usually absent in such cases. Fig. 22, Plate V, represents a good specimen of this kind observed in the cultures. The petiole $(p)$ was cylindrical and contained a well-developed vascular bundle $(v)$, shown only in part in the photograph. No stomata were found on any portion of the sporophytic growth. The cells $(c)$ in the flattened portion of the structure next to the terminal part of the petiole were columnar and presented a regular arrangement. There was a gradual change in the form of these cells towards the apical region $(a)$ which was already differentiated. A filamentous portion $(f)$, consisting of a single row of cells, had been produced from the prothalloid part of the outgrowth. Later an embryo was observed to begin its development directly behind the apical region $(a)$. Whether or not such a development of a gametophyte from a sporophyte of this nature is to be called apospory is a question of definition.

\section{The Sporophyte of Nephrodium hirtipes.}

Development of the Embryo. The embryo originates from cells posterior to the apical notch of the prothallium and on its ventral side. A lightcoloured region frequently appears either in the notch or at some distance behind it (Figs. 4, 5, 6, Jo, $\mathrm{I}$ I, Pl. V). It is in this light-coloured region that the embryo is usually formed. The cells of this region usually contain numerous colourless plastids, but few chloroplasts as compared with the 
neighbouring prothallial cells (Figs. 7 and $8, \mathrm{Pl}$. V). When prothallia are grown in weak light a larger proportion develop this light region. An early stage in the development of the embryo is shown in.Fig. $3, \mathrm{Pl}$. V. In this case only a few small superficial cells of the embryo are visible on the ventral side of the prothallium. The paler portion, so conspicuous in the prothallia represented by Figs. 4, IO, and $1 \mathrm{I}, \mathrm{Pl} . \mathrm{V}$, is absent in this instance. Sometimes tracheides appear in the portion of the prothallium just described ( $a$, Fig. IO, Pl. V), but these are not always present at so early a stage in the development of the embryo. The pale region is generally differentiated before the prothallium has reached its maximum size. The growth of the prothallium continues for some time even after the apical cell of the primary leaf and that of the primary root have been differentiated.

From numerous sections made of prothallia showing early stages in the development of embryos, it has not yet been determined whether a single superficial cell only is concerned in the formation of the embryo as described by Yamanouchi (1908 c) in Nephrodium molle. The embryo certainly begins its development very early and even before the cushion of the prothallium has been formed. The details of this development are reserved for future investigation.

The apical cell of the leaf of the embryo is differentiated first, then that of the root, and finally that of the stem. The stem rudiment appears between the base of the leaf and the prothallium. The root is endogenous. A foot, so far as I have been able to determine, is never produced.

As the embryo grows it involves a considerable portion of both the upper and lower parts of the prothallium. This is shown in Figs. $6(b$ and $c)$ and i 1, Pl. V. Fig. I 2 of the same plate is a dorsal view of the prothallium that is represented in ventral view in Fig. 11 . The extent of the tissue belonging to the embryo can be readily determined from the appearance of the cells in a stained section. The cells of the embryo are smaller than the prothalloid cells, and their cytoplasmic contents are much denser. The nuclei of the embryo are large in proportion to the size of the cells, although many appear to be no larger absolutely than the nuclei of the gametophyte. The vascular system which develops in the young embryo grows anteriorly into the leaf and posteriorly towards the root apex. A vascular strand also extends into the anterior portion of the prothallium and in the direction of the apex of the stem.

- Multicellular glandular hairs are produced on the young embryo. Sometimes similar hairs are borne also on the light region in the neighbourhood of the notch (Fig. 9, Pl. V).

While the leaf usually appears first in the development of the embryo (Figs. 13, 14, 15), in some cases the root develops before the leaf (Fig. 16, Pl. V). In still other cases the leaf and the root appear simultaneously (Figs. 
I 7-2I, Pl. V). Sometimes the leaf is developed from the surface of the prothallium (Fig. I9, Pl. V), and in a few instances it has been found that leaves are developed from both surfaces. Occasionally roots were observed to make their appearance on both surfaces of the prothallium. Secondary prothallia produce embryos in all essential respects similar to those formed by the primary prothallia. Large irregular prothallia whose form results from changes in the intensity of illumination may produce more than one embryo each (Fig. 24, Pl. V, $a$ and $b$ ), and these embryos may develop into normal sporophytes. Fig. $23, \mathrm{Pl} . \mathrm{V}$, represents a portion of a prothallium of irregular form with two embryos, each with a leaf and a root. On another portion of the same prothallium a third embryo had been produced.

A careful study was made to determine whether nuclear migrations and fusions similar to those described by Farmer and Digby (1907) occur among the vegetative cells of the prothallium previous to the development of the embryo. For this purpose both stained prothallia mounted whole and stained sections were studied. In not a single instance were nuclear migrations, nuclear fusions, or binucleate cells observed.

Sporogenesis. After it was discovered that in the sporangium of Nephrodium hirtipes the chromosome number is doubled in consequence of incomplete nuclear divisions in the manner described below, it appeared desirable to make as thorough a study as possible of the whole subject of sporogenesis. The observations on the sporogenous cells are based on prepared slides of thousands of sporangia in different stages of development. Most of the work was checked by a microscopical examination of living material. The presence of numerous nuclear division figures in the sporogenous cells belonging to the generations previous to the spore mother-cells, in tapetal cells, and in the wall cells of the sporangium, facilitated the counting of the chromosomes. In the dividing nuclei of cells of all these classes between sixty and sixty-five chromosomes were counted. The same approximate number of chromosomes was counted in dividing nuclei of the gametophyte and the young sporophyte.

The nuclear and cell divisions in the sporangium, preceding the stage at which eight sporogenous cells are present, are normal in every respect. At this stage the sporogenous cells are nearly isodiametric, although there are frequent exceptions, some of them being at times much elongated. The resting nucleus is large, although not so large as the new diploid nucleus formed at a later period. The resting nucleus passes through the normal prophase stages. At this time the tapetum is composed of two layers of cells. Normal division figures are not uncommon in the tapetal cells and the sporangial wall cells even, at a later stage.

The metaphases following these prophases are at first normal in appearance, when observed either from the side or in polar view (Fig. 24, Pl. VI). Instead, however, of the metaphases being followed by the 
anaphases and telophases in the usual order, a peculiar incomplete nuclear and cell division now occurs.

In the Iarge majority of cases only a number of the daughter chromosomes in the equatorial plate pass to the respective poles of the broad-poled spindle; In other instances the chromosomes appear to pass but a short distance towards the poles. The resting nucleus in the former instance will be either kidney-shaped or dumb-bell-shaped (Figs. 30, $3^{\mathrm{I}}, \mathrm{Pl}$. VI), and in the latter spherical (Fig. 26, Pl. VI). It is evident from the foregoing that the new nuclear membrane encloses all the nuclear material which in an ordinary division is distributed to two daughter nuclei. The new nucleus so established thus contains the diploid number of chromosomes.

Fig. 25, Pl. VI, was made from a longitudinal section of a sporangium. Five of the eight sporogenous cells are shown in the section, and in each case some of the chromosomes have passed to the poles of the spindle. In cell $a$ all the chromosomes appear to have passed to the poles, but the next section of the same nucleus shows many chromosomes between the two apparently separate groups shown in this figure. Fig. 27 of Pl. VI shows a similar but later stage. Only four of the sporogenous cells are shown in this case. The outlines of the cells are already becoming rounded, which fact indicates that they are to function as spore mother-cells. The chromosomes are beginning to anastomose preparatory to the passing of the nucleus into a resting condition. The nuclear membrane has already been formed and encloses therefore the diploid number of chromosomes. Later stages are represented by Figs. 28, 29, 30, 3I, 32, 33, and 34, Pl. VI. In some of the nuclei shown in these figures the nuclear material is beginning to pass into the resting condition. It appears that occasionally the nucleus passes into this condition before the nuclear membrane has been formed. It was impossible, however, to obtain any positive evidence on this point. It is not difficult to find in a sporangium of Nephrodium hirtipes nuclei of the different forms described in various stages of synapsis and in the heterotypic and homotypic divisions. It is certain that the cells with these nuclei function as spore mother-cells.

During synapsis a large number of the nuclei of the spore mother-cells are spherical in form. The number of nuclei of the kidney-shaped and the dumb-bell-shaped types becomes progressively smaller as the spore mother-, cells grow older. Unless the incomplete cell divisions to be described later progress too far, there is no reason to doubt that many nuclei, at first . irregular in form, later become spherical.

Frequently in the same sporangium spherical nuclei and nuclei of the irregular forms described are present. Often chromatin material in the different nuclei of the sporogenous cells in a sporangium is in the same stage. It appears, from an examination of numerous preparations, that in some instances the chromosomes in the equatorial plate of the eight-celled 
stage retain their position in the plate or pass only a short distance towards the poles of the spindle. Fig. 26, Pl. VI, represents a dividing nucleus in which the chromosomes have passed only a short distance towards the poles. The distribution of the chromosomes in this case may suggest a polar view of an equatorial plate stage, but in such a view and at an early stage the chromosomes present a more compact arrangement. Spindle fibres were demonstrated to be present in some cases at this time. From an examination of other sections of the same nucleus, it is probable that neither a kidneyshaped nor a dumb-bell-shaped nucleus will be formed from such a nucleus. Frequently a nearly spherical resting nucleus was found in a sporangium, while adjacent to it was a nucleus of the kidney-shaped type. The spherical nucleus in this case may have resulted from an incomplete nuclear division in which the chromosomes of the equatorial plate passed only a short distance towards the poles.

A number of nuclei in a sporangium become spherical at an early stage, and some sporangia were found in which the nuclei of all eight of the sporogenous cells were spherical, and in this case each nucleus was in the resting condition. Two assumptions can be made in regard to the origin of such nuclei. The resting nuclei of the first eight-celled stage may not divide and function as the nuclei of the spore mother-cells, or they may begin to divide, but the chromosomes may not pass to the poles. From what has been stated in regard to the history of the chromosomes in the equatorial plate, it is very probable that the latter assumption is true. In some sporangia, as previously stated, all the nuclei are either kidney-shaped or dumb-bell-shaped, while in other sporangia the nuclei vary from the spherical to the kidney or dumb-bell forms. It would not, therefore, be surprising to find a sporangium all of whose nuclei were spherical in form, even though an incomplete division had occurred in each.

Spindle fibres were in some instances stained with difficulty, and at first were overlooked. These fibres are shown in Figs. 24, 2.5, 27, 28, 29, of Pl. VI. In the cell shown in Fig. 28 a cell plate was already formed although no nuclear membrane was present. Sometimes the fibres are well developed, but there is no indication of a cell plate (Figs. 25 and 27, PI. VI). As the different longitudinal sections of nuclei indicate, spindle fibres are never present on the convex side of the nucleus. In a number of instances spindle fibres appeared to be absent even on the concave side of the nucleus. In some cases, on account of the distribution of the fibres, the plate formed on the spindle did not extend to the nuclear membrane (c, Fig. 27, Pl. VI). In the majority of cases, however, the plate extends from the wall of the cell to the nuclear membrane (Figs. 29-33, Pl. VI). In some instances the fibres are poorly developed or quite absent. This seems to be frequently the case when the nuclei are somewhat irregular in form. When spindle fibres are present a cell plate is often produced and a distinct cell wall is formed later, 
extending part way across the cell. Hence when a new wall is produced it extends from the wall of the cell to the concavity of the nucleus (Figs. $3^{\circ}$, $3^{1}, 3^{2}$, and 33 , PI. VI).

Fig. 32 , PI. VI. presents some evidence that if spindle fibres are formed during the division of the nucleus they may sometimes wholly or partially disappear before cell-wall formation. On the left-hand side of the figure the new walls are present, but on the other side no indication of such walls is observed. Fig. 33 was drawn from the same sporangium. Such figures are very infrequent and suggest that complete nuclear and cell divisions may occur in rare instances. It would be difficult to conceive how Fig. 33 could represent the result of a fusion of two sporogenous cells and their nuclei. The whole figure represents clearly a single cell, and the portions of it have been produced by an incomplete cell division. just described. Such a cell could be formed from one similar to $a$, Fig. $25, \mathrm{Pl}$. VI.

It appears, therefore, that the eight sporogenous cells undergo not only an incomplete nuclear division but also in some instances an incomplete cell division. That nuclear and cell divisions are not completed, except possibly in very rare instances, was determined by counting the sporogenous cells at various stages of development. Many spore mother-cells during the resting stage of the nucleus, synapsis, the heterotypic and the homotypic divisions, and spores showed evidences of incomplete division (Figs. 33, 34, Pl. VI, and Figs. $39,43,49,50,51$, and $52, \mathrm{Pl}$. VII). Hence there can be no question that cell and nuclear divisions rarely, if ever, occur during the first eightcelled stage of the sporogenous cells.

Except in the shape of the cell or its nucleus, nothing unusual was observed in the structure or behaviour of the sporogenous cells after the incomplete division just described. The nucleus and the cell increase considerably in size, and unless there is a well-developed spindle produced, and a partial division of the cell occurs, the majority of the cells and their nuclei finally become approximately spherical. A comparison of the sizes of the resting nuclei before and after the incomplete divisions shows that they are considerably larger at the latter stage. 'While the nuclear material is still in. the form of a reticulum, it recedes gradually from one side of the nuclear membrane. A continuous spireme appears to be formed as the nucleus passes into synapsis. Fig. 35, Pl. VI, represents an early stage in this continuous spireme thread. The compact synaptic mass that finally appears pressed against the membrane on one side of the nucleus includes the nucleolus, which seems to persist during the contraction stage (Fig. $36 ; \mathrm{PI}$.VI). When the spireme emerges from synapsis, radiating portions of the thread extend to the nuclear membrane on the side opposite that at which the contraction took place. During the synaptic period the cytoplasmic portion of the mother-cell, where the synaptic mass is present, is very thin. After synapsis the cytoplasm of the mother-cell gradually grows to a nearly 
uniform thickness. The mother-cells grow considerably while the foregoing changes are taking place, although they vary much in size at any particular stage. Fig. 39, Pl. VII, is drawn from a flattened spore mother-cell and hence appears unusually large. The details of chromosome formation were not followed. In diakinesis (Figs. 37 and $3^{8}, \mathrm{Pl}$. VI, and Fig. 39. PI. VII) the chromosomes were counted, and there were found to be present at this time between sixty and sixty-five bivalent chromosomes. A multipolar spindle is formed which becomes bipolar (Figs. 40 and $4 \mathrm{I}, \mathrm{Pl}$. VII). The various stages in the division of the nuclei of the spore mother-cells were studied, and in the vast majority of cases the divisions are in every way normal (Figs. 42 , $43,44,45,46, \mathrm{Pl}$. VII). Sometimes anaphase figures were found in both the heterotypic and homotypic divisions with lagging chromosomes (Fig. 42, Pl. VII). During the metaphase of the heterotypic division a few of the chromosomes pass to the poles while the remainder are still in the equatorial plate. Between the heterotypic and the homotypic divisions the individual chromosomes can be readily distinguished (Fig. 43, Pl. VII).

During the heterotypic division a granular zone appears in a broad equatorial plate midway between the daughter nuclei. This zone stains heavily and is composed of numerous small granules of cytoplasmic material (Figs. $43,44,45$, and $46, \mathrm{Pl}$. VII). In the homotypic division the axis of the spindles may be parallel (Fig. 45, Pl. VII), oblique (Fig. 46, Pl. VII), or perpendicular to one another, or the axes of the two may lie in the same line.

As a result of the division of the spore mother-cells thirty-two spores are produced, each having the reduced number of chromosomes, namely between sixty and sixty-five. Frequently the chromatin material in each member of the young tetrad is aggregated at one side of the nucleus and a clear region appears on the opposite side (Fig. 47, PI. VII). The cells in the preparation from which the figure was drawn showed no signs of plasmolysis, and since the same appearance was observed when different fixing fluids were used, this condition of the nucleus is not likely to have resulted from the technique employed. There is considerable growth in the size of the spores before the thick wall is formed about each one (Fig. 48 , Pl. VII). Sometimes chromatic material is found in the cytoplasm of the young spore (Fig. 54, Pl. V.II). The origin of the nuclear material may be traced to chromosomes left in the cytoplasm during the division of the spore mother-cell nucleus.

Since a number of sporogenous cells during the eight-celled stage were found in which the divisions were almost completed, it seemed probable, as I have already suggested, that at least in some cases such divisions may occur. A large number of preparations were examined, but no instance of such a division was found. The cells at different stages were also counted, and in only two cases observed did it appear that more than eight mother- 
cells had been formied in a sporangium. In one sporangium three undivided mother-cells and six tetrads were found. There must have been at an early stage, therefore, nine spore mother-cells. One of the eight sporogenous cells which ordinarily undergo the incomplete division already described presumably completed its division in this case, and thus the additional spore mother-cell may have resulted. In one other instance more than the usual number of tetrads was found in a sporangium. In this case there were eleven tetrads, six showing evidences of incomplete divisions, and five of complete divisions. Fig. 53, Pl. VII, represents one the tetrads with incompletely divided cells. In the plane of the section only one of the cells and its nucleus indicated that the divisions never had been completed. However, the other: cell and its nucleus showed similarly that incomplete divisions had occurred. If three of the eight sporogenous cells which as a rule undergo the incomplete divisions described divided, three additional cells would be produced. The other five cells would undergo the usual divisions in the formation of the tetrads; but six of the cells, it may be supposed, would show abnormalities in the divisions. From such a single instance it is, of course, unsafe to draw any positive conclusions. The two sporangia here described were the only ones which afforded evidence that a complete division of one or more of the eight original sporogenous cells may occasionally occur.

Sometimes, on account of the shape of the spore mother-cell and its nucleus, the chromatin material may be divided during synapsis into two nearly equal masses. In one instance two nearly distinct chromosome groups were observed during diakinesis in a dumb-bell-shaped nucleus. As a result of the usual divisions eight nuclei may be produced. When the spore mother-cells are kidney-shaped or dumb-bell-shaped, the chromosomes during the anaphase of the heterotypic division at one or both of the poles may occasionally be separated into two groups (Fig. 49, Pl. VII). The separation of the chromosomes in this instance is clearly brought about by the indentation of the mother-cell resulting from the original incomplete division. Each of the three nuclei represented in this figure may divide (Fig. 50, P1. VII) and six spores may be formed. Fig. 52, Pl. VII, shows five of the six nuclei which result in such a case. Several metaphase figures were found in the preparations similar to that shown in Fig. 50, but only one spore mother-cell containing three anaphase figures was observed (Fig. 5I, Pl. VII). That the two smaller division figures represented in the figure resulted from a division of one of two groups of chromosomes produced during the anaphase of the heterotypic division cannot be stated with certainty. When there are two indentations in the spore mother-cell there might conceivably be produced during the anaphase of the heterotypic division four chromosome groups, and in consequence of the following division eight spores might be formed from a single spore mother-cell. No 
such instances were observed in any of my preparations. Whether such spores whose nuclei do not possess the normal number of chromosomes have the power to germinate has not been determined.

The formation of more than four spores from a single spore mother-cell has been reported in Angiosperms by various investigators. Wille (1886) gives a summary of the early literature of the subject and reports also his own discoveries. Strasburger (1892) and Juel (1897) found that the supernumerary pollen grains of Hemerocallis fulva are produced by the formation of cells whose nuclei originate from chromosomes which fail to pass to either pole during the division of the spore mother-cell. Fullmer (1899) observed in the same species that occasionally some of the nuclei of the spore-tetrads divide, and that as a result of these divisions additional microspores are produced. Miss Lyon (1898) reported that in Euphorbia corollata sometimes five or six microspores are produced in place of the usual four spores of a tetrad. No explanation is given for the presence of the supernumerary spores in this plant. So far as I know, the formation of more than four spores from a spore mother-cell has not previously been described in any of the Bryophytes or Pteridophytes.

\section{Discussion.}

In my preliminary note ( $1915 \mathrm{~b}$ ) I described cell and nuclear fusions in the sporangia of Neplerodium hirtipes similar to those described by Miss Allen (1911) in Aspidium falcatum. Since sporangia of Neplirodium hirtipes were found containing eight sporogenous cells whose nuclei in somc cases were in prophases and in other cases in metaphases, it seemed that the completion of the divisions must result in the formation of sixteen sporogenous cells in each sporangium. In older sporangia figures were found which seemed to show that these sixteen cells were fusing in pairs. The presence of thirty-two spores in each sporangium, evidently produced by the division of eight spore mother-cells, apparently confirmed this conclusion. However, a later and more extended study of additional preparations, which contained an abundance of division figures, has shown that the divisions first initiated at the stage of the eight sporogenous cells are never or very rarely completed; that these incomplete divisions result in irregular cell and nuclcar forms, as well as in the partial division of the cells by cell-plates or walls, which were first interpreted as evidences of cell fusion; and that the result of these incomplete divisions, as indicated in what precedes, is a doubling of the number of chromosomes in each of the eight cells which then proceed to function as spore mother-cells. A later examination of my older preparations shows, as a matter of fact, that they contain very few carlier stages in incomplete nuclear and cell division, and hence the most important evidence on the history of the sporogenous cells was not at first obtained. 
Miss Allen's figures of the sporogenous cells of Aspidium falcatum are so similar to many of those which I have obtained in Nephrodium hirtipes as to make it seem probable that a further study of the former species may show that in it also the divisions first initiated at the stage of the eight sporogenous cells are, except in very rare cases, never completed. Her Fig. 44, Pl. III, representing an early stage in fusion, may be interpreted as showing a completed nuclear division and a nearly completed cell division, and if this be a correct interpretation the division shown in this case has progressed farther than any I have observed in Neplrodimm. However, in some instances, as in Fig. 3.3, Pl. VI, my preparations show a near approach to a complete division of the cell and its nucleus.

In three cases Miss Allen found more than eight spore mother-cells in a sporangium of Aspidium falcatum. The larger number of spores was accounted for by the failure of some of the sporogenous cells to fuse in pairs. In two instances I found that more than eight sporogenous cells must have been produced in a sporangium of Nephrodium hirtipes. If in thesc instances any of the sporogenous cells complete their divisions, more than eight spore mother-cells will be formed. No evidence has been presented by either Miss Allen or myself to indicate that the spore mother-cells which do not possess the diploid number of chromosomes have the power to divide. Six of the eleven tetrads found in a single sporangium of Nephrodium (Fig. 53, Pl. VII) showed that abnormalities had occurred in the division of the mother-cells, which, as has been previously suggested, may have been produced from sporogenous cells that completed their divisions and hence did not have the diploid number of chromosomes. Since more than four spores are sometimes produced from a single spore mother-cell of Nephrodium hirtipes, no conclusion can be drawn from the number of spores in a sporangium in regard to the possibility of the division of the supernumerary spore mother-cells. It is evident, however, that spores may be formed with nuclei which have not received the haploid number of chromosomes (Figs. 50, 5I, and 52, Pl. VII).

The formation in many instances of a spindle, and not seldom of a cell plate extending part way across the cell, and the distribution of the chromosomes from the equatorial plate exclude the possibility that the irregular nuclear figures which I have found in the eight sporogenous cells of Nephrodium hirtipes can in any case represent amitotic division. Amitosis, also, cannot occur at any later stage, since in such a case more than thirtytwo spores would then be produced.

In apogamous ferns three cases have been reported in which 'substitution fusions' are thought to occur-that is, fusions of cells (or nuclei) other than those which are morphologically gametes, by means of which the diploid number of chromosomes is established. In the two Lastraea varieties studied by Farmer and Digby $(1907)$, in which the fusion is between nuclci 
of two vegetative cells of the prothallium, the haploid number of chromosomes characterizes the gametophyte, the diploid number the sporophyte. In Aspidium falcatum, in which according to Miss Allen (1911) the fusion is between sporogenous cells, chromosome reduction immediately following, the haploid number of chromosomes is characteristic of both generations. So far as the chromosome number is concerned the same condition prevails in Nephrodium hirtipes as in Aspidium falcatum.

The chromosome number in other apogamous ferns, so far investigated, is of interest. As a result of induced apogamy in Nephrodium molle, according to Yamanouchi (1908 a, b, and c) the haploid number is found in both the gametophyte and the sporophyte. Farmer and Digby (1907) think that in Lastraea pseudo-mas var. cristata apospora both generations possess the haploid number of chromosomes. On the other hand, the same investigators found that in Athyriim Filix-foemina var. clarissima, Jones, the diploid number of chromosomes persists throughout both generations. Thus it appears from the studies so far made of apogamous ferns, as well as by evidence from other groups of plants, that the characteristic differences between gametophyte and sporophyte are not determined alone by differences in the chromosome number, but that the sharply contrasted developmental possibilities of spore and zygote are governed by other factors which are as yet entirely unknown.

Apogamy in ferns developed in all probability at a late period in the evolution of the homosporous ferns. So far no certain case of apogamy has been discovered in the Eusporangiatae. Jeffrey (1896), however, believed that he found in one instance evidence of apogamy in Botrychizum virginianum. A large number have been found among the Polypodiaceac, the most highly specialized, and probably the moṣt recent, homosporous leptosporangiate family.

In regard to the origin of apogamy in Nephrodium hirtipes three possibilities are presented. If at one time in the life-history of the fern fertilization was by some means suppressed, the archegonia may have disappeared and fertilization have thus been rendered impossible. The embryo may then have arisen as a vegetative outgrowth. As a substitution for fertilization the incomplete divisions described in this paper may have occurred. Why a doubling of the number of chromosomes should still be necessary for the maintenance of the life-cycle is difficult to explain, since, as has just been stated, in Lastraea pseudo-mas var. cristata apospora the haploid number of chromosomes remains unchanged throughout both generations, and although Yamanouchi (1908) did not investigate sporogenesis in the apogamously produced sporophytes of Nephrodium molle, it is probable that the gametophyte number is maintained in both generations of the fern.

On the other hand, the occurrence of incomplete nuclear divisions 
in the sporangium of Nephrodium litrtipes may have preceded the appearance of apogamy. If the number of chromosomes was not at first reduced, the act of fertilization was rendered unnecessary, and hence the embryo may have arisen at first parthenogenetically and later apogamously. If the latter view is held, the double number of chromosomes would be present throughout the life-history. However, on the basis of other investigations of different apogamous species, it is probable that the chromosome number. now characteristic of both generations of Nephrodium hirtipes is the original haploid number, and hence it seems likely that apogamy may have arisen before the incomplete nuclear divisions were established. These views regarding the origin of apogamy are similar to those expressed by Miss Allen (1911) with reference to Aspidium falcatum.

Although so far no cytological evidence has been presented to confirm the occurrence of hybridization in ferns, it is possible that Nephrodium hirtipes and perhaps some other apogamous ferns may be of hybrid origin, and that the abnormalities which I have described have resulted from fertilization between two more or less closely related species.

\section{Summary.}

I. The prothallium of Nephrodium hirtipes is produced by the germination of a spore.

2. The gametophyte never produces archegonia, but antheridia are formed which develop apparently normal antherozoids.

3. The development of secondary prothallia is readily induced by cultural conditions.

4. Attempts to induce an aposporous gametophyte development in this species have been successful only in rare instances.

5. The embryo originates at an early stage in the development of the gametophyte as a vegetative outgrowth of the prothallium. The apical cell of the leaf is first formed, and then that of the root, and later that of the stem. A foot is never produced. The later stages in the development of the embryo resemble those of the ordinary fern embryo produced as a result of fertilization.

6. At no time have nuclear migrations and fusions been observed to occur in the prothallium when the embryo begins its development.

7. At the stage when the sporangium contains eight sporogenous cells, an incomplete nuclear and cell division occurs in each of thesc eight cells. As a result of the incomplete divisions, each nucleus contains the diploid number of chromosomes-between 120 and 130 . The eight sporogenous cells, now diploid, function as spore mother-cells. The spores formed from these cells have the haploid number of chromosomesbetween 60 and 65 -and this number is retained in the cells of both the gametophyte and of the apogamously developed sporophyte. 


\section{Steil.-Apogamy in Nephrodium hirtipes, Hk.}

8. Thirty-two spores are ordinarily produced in a sporangium of Nephrodium lirtipes. The smaller number of spores which sometimes occur is to be accounted for by abnormalities in the nuclear condition of the spore mother-cell.

9. A larger number than thirty-two spores is sometimes produced by the formation of more than four spores from a single spore mothercell. In rare instances more than eight spore mother-cells appear to be produced in a sporangium. Whether in such a case all the spore mother-cells can form normal tetrads and spores has not been determined.

To Professor C. E. Allen I wish to express my thanks for helpful suggestions and criticisms received during the progress of the foregoing investigation.

\section{BIBLIOGRAPHY.}

Abbot, Jamrs (1874): Scalariform Ducts in Prothallia. Quart. Journ. Mic. Sci, nèw ser., xiv. $401-2$.

Allen, R. F. (1911): Studies in Spermatogenesis and A pogamy in Ferns. Trans. Wis. Acad. Sci., Arts, and Letters, xvii. I-44.

Berggren, S. (1888): Ueber Apogamie von Nothochlaena. Bot. Cent., xxxv. I83-4.

Black, Caroline A. (1909): The Development of the Imbedded Antheridium in Dryopteris. stipularis (Willd.), Maxon, and Nephrodium molle. Bull. Tor. Bot. Club, xxxvi. :57-72. .

Bower, F. O. (1888): On Some Normal and A bnormal Developments of the Oophyte of Trichomantes Ann. Bot., i. $269-305$.

DE BARY, A. (1878): Ueber apogame Farne und die Erscheinnng der Apogamie im allgemeinen. Bot. Zeit., $x \times x v i .449-87$.

Digby, L. (1905) : Preliminary Note on A pospory. Proc. Roy. Soc., $76 \mathrm{~B}, 463-8$.

Farlow, W. G. (1874): An Asexual Growth from the Prothallium of Pteris cretica. Quart. Journ. Mic. Sci., xiv. 266-72.

Farmer, J. B., and DigBy, L. (1907) : Studies in Apospory and Apogamy in Ferns. Ann. But., xxi. 16 i -99 .

Farmer, J. B., Moore, J. E. S., and Diguy, L. (1903): On the Cytology of Apogamy and A pospory. 1. Preliminary Note on Apogamy. Proc. Roy. Soc., lxxi. 453-8.

FuLLMER, E. L. (1899): The Development of the Microsporangia and Microspores of Hemerocallis fulva. Bot. Gaz., xxviii. 81-8.

Goebel, K. (1905): A posporie bei Asplenium dimorphum. Flora, xcv. 239-44.

HeIM, CARL (1896): Untersuchungen über Farnprothallien. Flora, 1xxxii. 329-73.

HeIlbron N, A. (1910): A pogamie, Bastardierung und Erblichkeitsverhältnisse bei einigen Farnen. Flora, ci. 1-42.

JEFFREY, E. C. (1896): The Gametophyte of Botrychium virginianum. University of Toronto Studies, Biol. Ser. No. 1, pp. 1-32, Pl. I-ł.

Juel, H. O. (1897): Die Kerntheilungen in den Pollenmutterzellen von Hemerocallis fulva und die bei denselben auftretenden Unregelmässigkeiten. Jahrb. für wiss. Bot., xxx. 205-26.

Lang, W. H. (1898): On Apogamy and the Development of Sporangia from Fern Prothallia. Phil. Trans. Roy. Soc., London, cxc B, 187-239.

Lgirgeb, H. (1885) : Die Sprossbildung an apogamen Farnprothallien. Ber. Dent. Bot. Ges., iii. $169-76$. 
I.eszcyc-Suminski, J. (1848) : Zur Entwickelungsgeschichte det Farmkräıter. Berlin.

Lyon, Florfencb M. (1898): A Contribution to the Life-history of Euphorbia corollata. Bot. Gaz., xxv. $418-26$.

Mercki.rv, C. E. (1850): Beobachtungen a. d. Prothallium der Farrnkräuter. St. Petersburg.

Moore, G. T. (1903): Methods for growing Pure Cultures of Algae. Jour. Appl. Microscopy, vi. $2309-14$.

Mottier, D. M. (1915): Beobachtungen über einige Farnprothallien mit bezug auf eingebettete Antheridien und Apogamie. Jahrb. für wiss. Bot., Ivi. $65-84$.

Naga I, Isuburo (1914) : Physiologische Untersuchungen über Farnprothallien. Flora, cvi. 281-330.

PaCe, Lula (1913): Some Peculiar Fern Prothallia. Bot. Gaz., 1. 49-58.

SAdebeck, R. (1879): Schenk, Handbuch der Botanik, i. $23^{\mathrm{I}-5}$.

STANGE, F. T. (1887): Mittheilung iilser seine Farnkulturen und die bei denselben beobachtete A pogamie. Sitz. Bot. Ges., Hamburg, I 886 . Also Just's Bot. Jahresber., cli. 598 .

STEıL, IW. N. (1910): Apogamy in Pellaea atropurpurea. Bot. Gaz., xlii. 400-1.

(1915 a): Some New Cases of Apogamy in Ferns. Prel. Note. Sci., N.S., xli. 293-4. (1915 b): Apogamy in Nephrodium hirtipes. Bot. Gaz., lix. 254-5.

(1918): Studies of some New Cases of Apogamy in Ferns. Bull. Torr. Club, 45, pp. 93-108, Pl. $4-5$.

Strphens, E. L., and Sykes, M. G. (1910) : Preliminary Note on Apogamy in Pteris droogmantiana. Ann. Bot., xxiv. 487 .

Strasburger, E. (1892): Ueber den Theilungsvorgang der Zellkerne lind das Verhältniss der Kerntheilung zur Zelltheilung. Archiv Mikr. Anat., xxi. 476-590.

Wigand, A. (1849): Zur Entwickelungsgeschichte der Farnkräuter. Bot. Ztg., vii. 105-7.

Wille, N. (1886): Ueber die Entwickelungsgeschichte der Pollenkörner der Angiospermen und das Wachsthum der Membranen durch Intussusception. Christiania Vidensk. Selskabs Forh., I 886 .

Woronin, H. (1907): Apogamie und Aposporie bei einigen Farnen. Ber. Deut. Bot. Ges., xxv. $8 ;-6$.

(1908): Apogamie und Aposporie bei einigen Farnen. Flora, xcviii. 10I-62.

Yamanovchi, S. (1908a): Spermatogenesis, Oogenesis, and Fertilization in Nephrodium. Bot. Gaz., xlv. $145-75$.

(1908 b) : Sporogenesis in Nephrodium. Ibid., I-3o.

(1908 c): Apogamy in Nephrodium. Ibid., 289-3 I9.

\section{EXPLANATION OF PLATES V-VII.}

Illustrating Dr. W. N. Steil's paper on Apogamy in Nephrodium hirtipes.

The photo-micrographs on Plate V represent different magnifications. The young sporophytes from which photographs $13^{-21}$ and 23 were made are magnified about $2 \frac{1}{2}$ diameters. The figures on Plates VI and VII, excepting 29, 30, and 31 , were drawn with a Zeiss compensating ocular No. 12, and apochromatic objective, $2 \mathrm{~mm}$. N. A. 1.30, at table level with the aid of a camera Jucida. With a tube elongation of $\mathrm{I}_{42} \mathrm{~mm}$. a magnification of about 2, $\mathrm{I}_{5} \mathrm{O}$ diameters was obtained. Figs. 29, 30, and $3 \mathrm{I}$ represent a magnification of about 1,250 .

\section{PLATE V.}

Fig. I. A dorsal view of a young prothallium.

Fig. 2. A dorsal view of a young prothallium just before the embryo becomes visible.

Fig. 3. An older prothallium, viewed from the ventral side. The small dark region prsterior to the apical notch represents the outer cells belonging to the young. embryo.

Fig. 4. A dorsal view of a highly magnifed portion of a prothallium. The embryo is visible as a compact area in the paler portion.

Fig. 5. A dorsal view of an older embryo. 
Fig. 6. Dorsal views of three prothallia at different stages of development. Paler portion of the prothallium produced before the embryo appears shown in $a$. In both $b$ and $c$ light areas and young embryos shown.

Fig. 7 . A highly magnified view of a small portion of a 'light' region.

Fig. 8. A highly magnified view of a small portion in the neighbourhood of the light region.

Fig. 9. A highly magnified portion of the apical region of a prothallium after the embryo has begun its development. $h$, multicellnlar hair. portion.

Fig. 10. A portion of a prothallium showing the apical region and tracheides, $t$, in paler

Fig. I r. A highly magnified view of a prothallium, dorsal view. $h$, multicellular hair produced ${ }^{\circ}$ on young embryo.

Fig. I2. Ventral view of the same prothallium.

Figs. 13, 14, I5. Young embryos with leaves developed in advance of the roots.

Fig. 16. An embryo with a root produced in advance of the leaf.

Fig. I 7. Embryo with leaf deveioped on the dorsal side of the prothallium.

Fig. I 8. An embryo whose root and leaf have grown to about the same length.

Figs. I9, 20. Young embryos. Leaves in advance of the roots.

Fig. 21 . An embryo with three leaves.

Fig. 22. A prothallium obtained from a young embryo when a culture was placed in weak illumination. $p$, petiole-like portion of a leaf; $c$, flattened outgrowth with elongated cells; $a$, apical region of gametophytic portion; $f$, filament.

-Fig. 23. A prothallium on which three apogamously produced embryos were formed. Two of these are shown in the photograph.

\section{PLATE VI.}

Fig. 24. Equatorial plate of the eight-celled stage of the sporogenous cells.

Fig. 35. Five of the eight sporogenous cells drawn from a longitudinal section of a sporangium. In the dividing nuclei some of the chromosomes bave passed to the poles. Spindle fibres present. the poles.

Fig. 26. A dividing nucleus of one of the eight cells. The chromosomes have not passed to

Fig. 27. Four of the eight sporogenous cells drawn from a longitudinal section. The chromosomes are beginning to lose their identity $c$, clear region where no spindle fibres are present; $a$, nuclear membrane encloses in each cell the diploid number of chromosomes.

Fig. 28. Some of the chromosomes have passed to the poles. Spindle fibres and cell-plate present.

Fig. 29. A later stage. Spindle fibres and cell-plate shown on the cuncave side of the nucleus.

Fig. 30. A kidney-shaped nncleus. A wall has been produced on the concave side of the nucleus.

Fig. 3r. A dumb-bell-shaped nucleus. Wall shown extending to the concavity of the nucleus.

Fig. 32. A dumb-bell-shaped nucleus. Cell division has progressed still farther than in the preceding stage. Cytoplasm on one side of the nucleus divided into two distinct portions, and a partial separation of the latter has resulted.

Fig 33. A dumb-bell-shaped nucleus. There was produced in this case a nearly complete nuclear and cell division.

Fig. 34. A kidney-shaped nucleus. The cell is beginning to round up. The indentation on the left-hand side of the figure is the result of incomplete cell division.

Fig. 35. A spore mother-cell whose nucleus is preparing for synapsis.

Fig. 36. The nucleus of the spore mother-cell just emerging from synapsis.

Figs. 37 and 38 . The chromosomes during diakinesis. Fig. 37 represents an early stage.

\section{PLATE VII.}

Fig. 39. A much flattened spore mother-cell at the same stage as represented in Fig. 15. Indentation shown on one side as a result of incomplete cell division.

Fig. 40. The heterotypic division. Spindle, multipolar.

Fig. 4l. Equatorial plate stage of the heterotypic division. Spindle bipolar.

Fig. $4^{2}$. An anaphase of the heterotypic division. Some lagging chromosomes shown. 
Fig. 43. A telophase stage of the heterotypic division. Granular zone present.

Fig. 44. Metaphases of the homotypic division. Spindle multipolar.

Figs. 45 and 46 . Anaphase stages of the homotypic division.

Fig. 47. A young tetrad. A clear region on one side of the nucleus.

rig. 48. An older tetrad.

Fig. 49. An anaphase stage of the heterotypic division, showing how one of the two sets of chromosomes may be divided into two groups.

Fig. 5o. A metaphase stage following the stage represented by Fig. 26.

Fig. 5I. An anaphase stage.

Fig. 52. A spore mother-cell from which six spores have been produced, five of which are shown in the figure.

Fig. 53. A tetrad, the members of which have been incompletely divided.

Fig. 54. Two young spores of the same tetrad. Chromatin material in the cytoplasm. 

Annats of Botany,
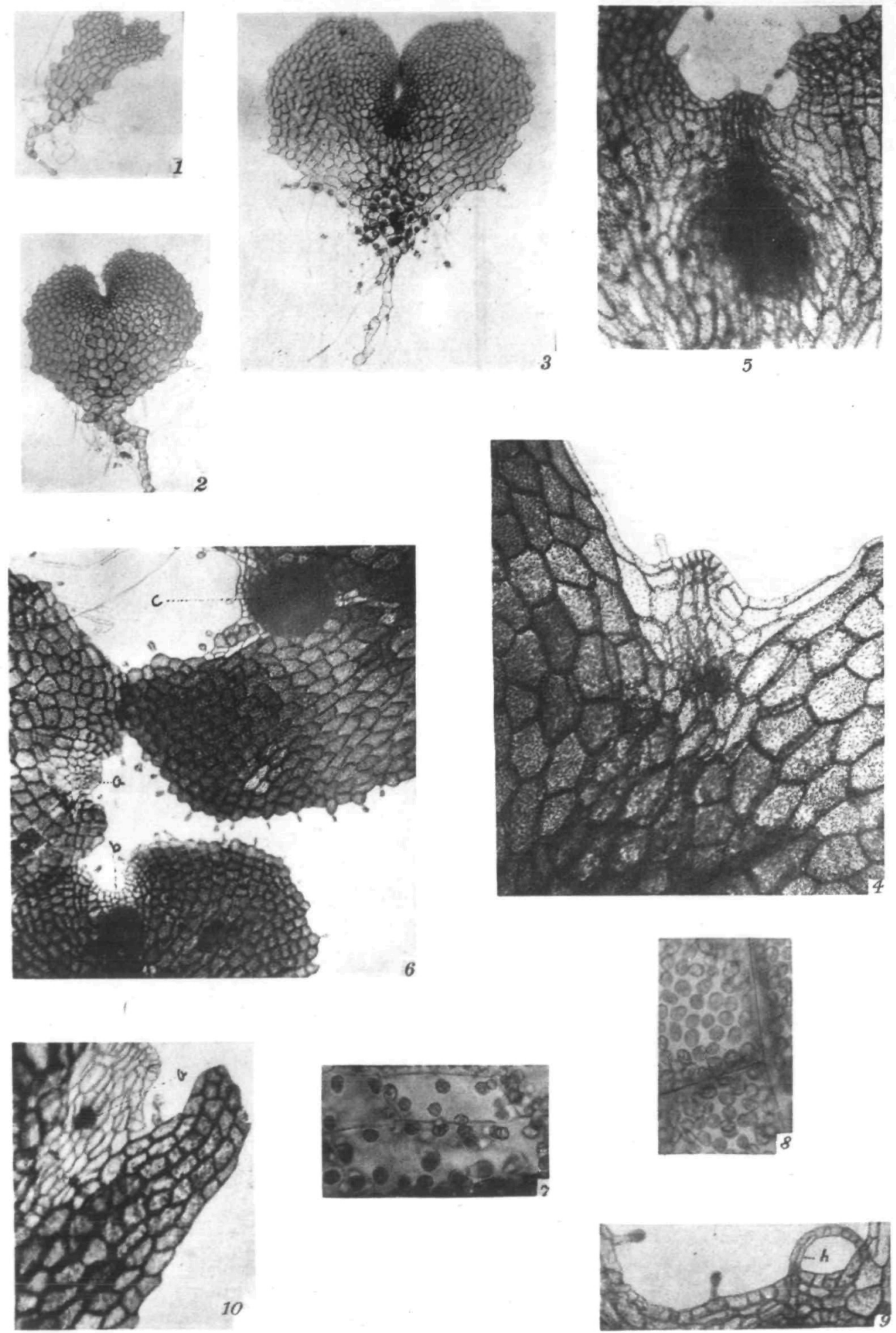

W. N. STEIL- NEPHRODIUM HIRTIPES. 
Vol. XXXII,, L.V.
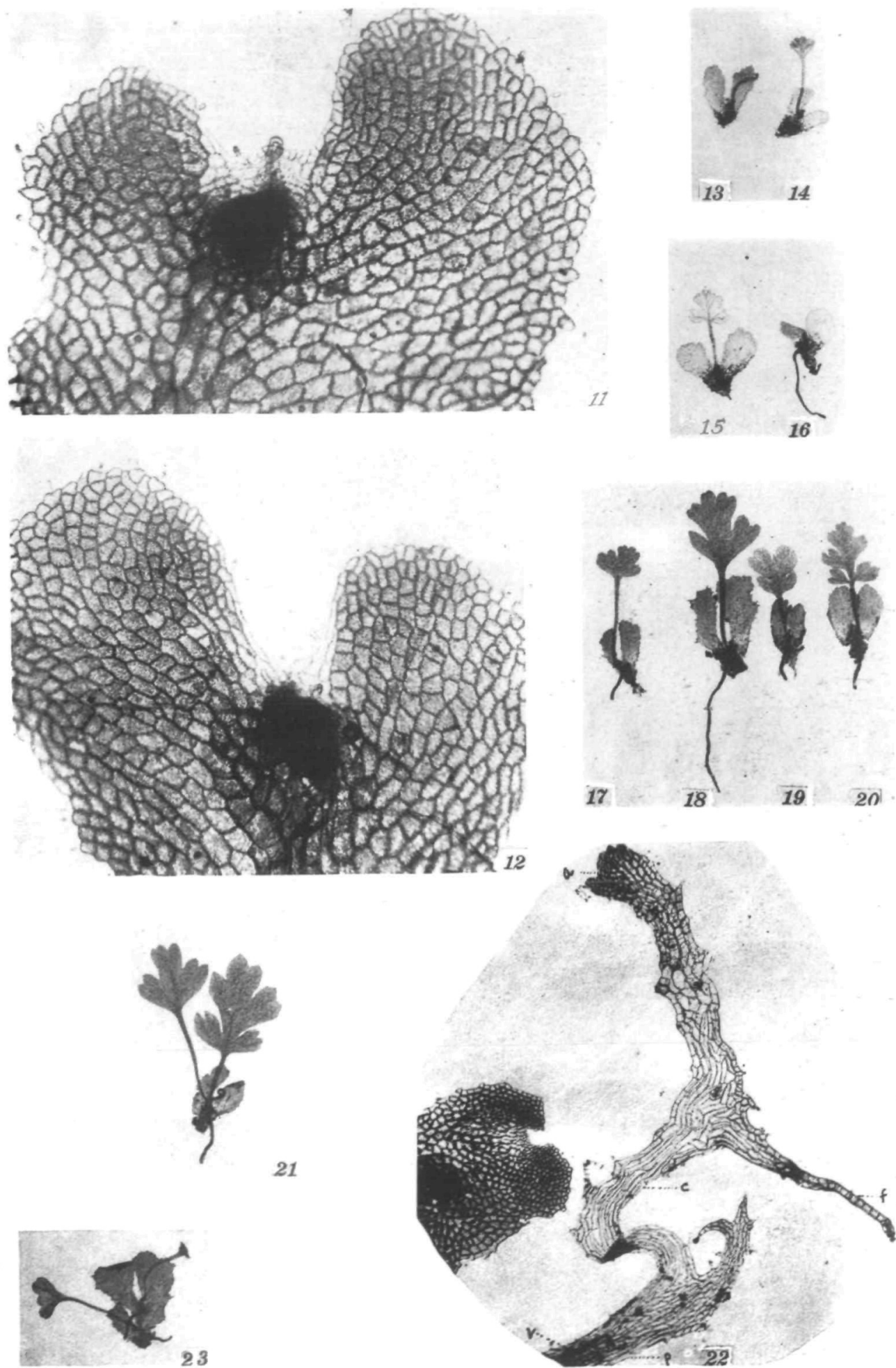
$!=$ 


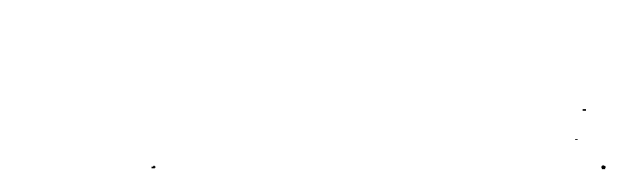


Anrals of Botany,
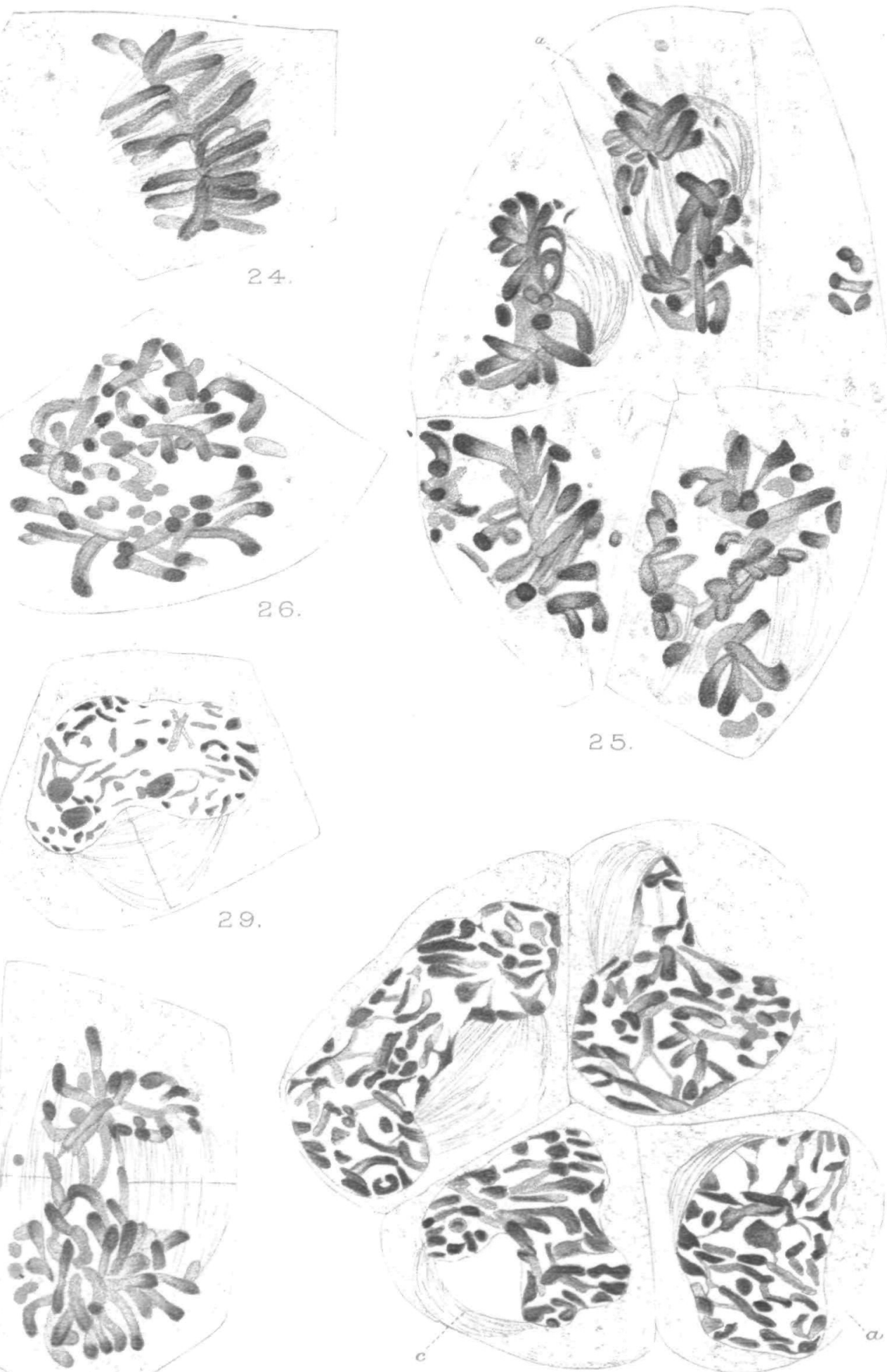

28.

W. N.STEIL - NEPHRODIUM HIRTIPES. 

Anrals of Botary,

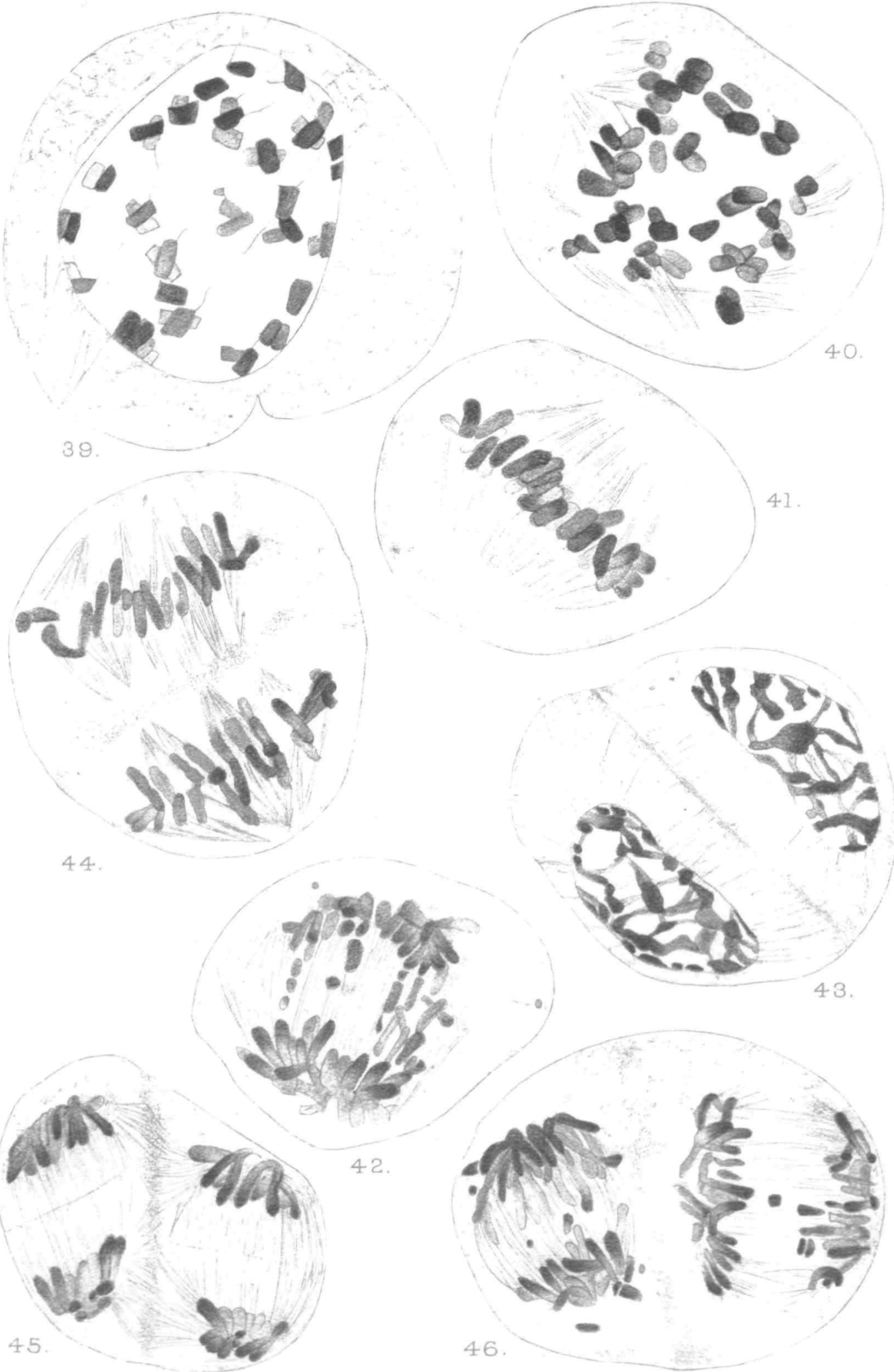

W. N. STEIL - NEPHRODIUM HIRTIPES. 

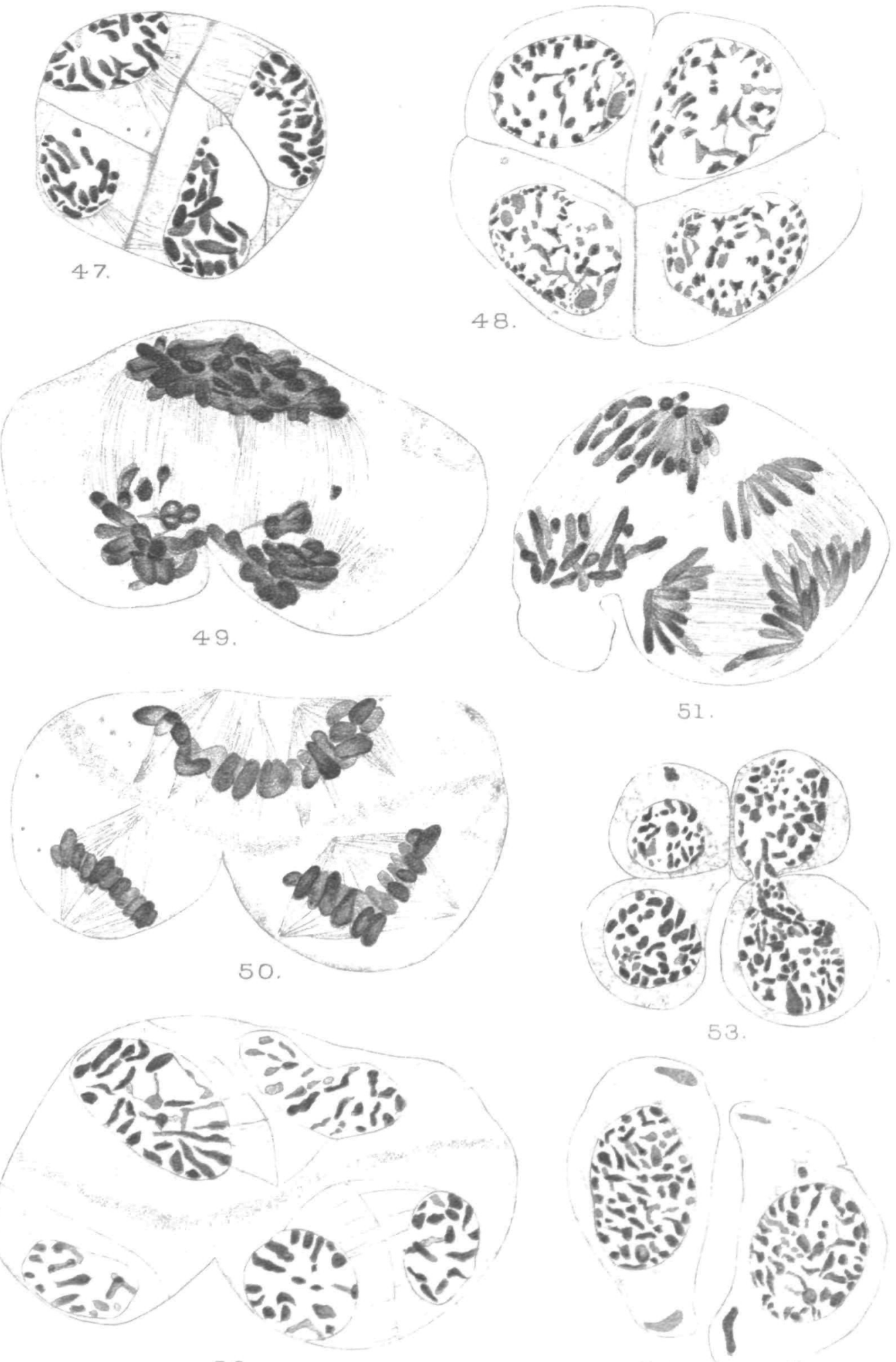

52. 
